\title{
Immunochemical Staining of the Rat Adenohypophysis in Organ Culture'
}

\author{
ALICE S. PAKURAR, ${ }^{2}$ RAYMOND H. KAHN AND JAMES L. CONKLIN ${ }^{3}$ \\ Department of Anatomy, The University of Michigan, Ann Arbor, \\ Michigan 48104
}

\begin{abstract}
Rat anterior pituitaries were cytologically studied following cultivation in organ culture, with and without the addition of hypothalamic and cortical extracts. Although five distinct cell types could be identified with classical stains in the uncultivated glands, the peroxidase-labeled antibody technique (using antibodies against STH, LTH, FSH, LH and TSH) showed that not all of the immune-specific cell types were being identified with the classical stains. This discrepancy was magnified following culture as chromophilic cells seen with classic stains decreased in number with an increase in culture time. The peroxidase technique, however, revealed that all cells remained constant in type and number regardless of time in culture. While the addition of either hypothalamic or cortical extract to the culture medium produced cytological alterations demonstrated by the classical dyes, the antibody technique showed no such alterations. Such a comparison of staining techniques emphasizes the hazards of relying solely on histological procedures to reveal the hormonal activity of the pituitary gland.
\end{abstract}

The removal of the anterior pituitary from its hypothalamic control results in a gland whose physiology is dramatically altered: prolactin is secreted in great quantities while all other anterior pituitary hormones are secreted at minimal levels (Sanders and Rennels, '59; Everett and Nikitovitch-Winer, '63). The cytological changes which accompany this altered function have been examined at various intervals after pituitary isolation (Nikitovitch-Winer and Everett, '59; Sanders and Rennels, '59; Rennels, '62; Pasteels, '63), but these changes have not been examined in a series of sequential intervals by the same investigator(s). Consequently, the various isolation techniques involved, the variety of stains used in light microscopic studies, and/or the difference in isolation periods make a compilation of data from these several sources somewhat difficult to integrate and interpret.

In this study we have histologically examined the rat anterior pituitary gland after various time periods in organ culture, adding hypothalamic or control neural extracts to the media of some of the cultures. Classical pituitary stains and the peroxi- dase-labeled antibody technique were used. An antibody technique was selected because of the greater specificity involved with the use of an antibody as compared with the classical dyes. The peroxidase technique, in turn, was chosen over a fluorescent antibody technique for several reasons. First, the paraffin embedded sections used would not only provide permanent slides but also would allow alternate sections to be treated with classical stains and the peroxidase procedure. Secondly, the small molecular weight of the peroxidase increases the sensitivity of the technique by allowing for ready penetration of the peroxidase-antibody complex into tissue sections (Nakane and Pierce, '67).

We have tried to interpret the histologi-

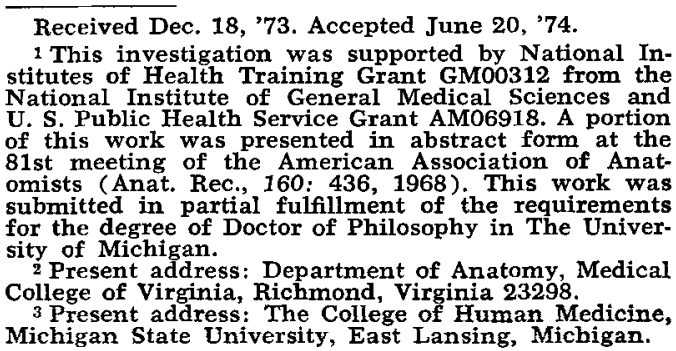

Received Dec. 18, '73. Accepted June 20, '74.

1 This investigation was supported by National Institutes of Health Training Grant GM00312 from the National Institute of General Medical Sciences and U. S. Public Health Service Grant AM06918. A portion of this work was presented in abstract form at the 81st meeting of the American Association of Anatsubmitted in partial fulfilment of the requirements for the degree of Doctor of Philosophy in The University of Michigan.

College of Virginia : Richmond, Virginia 23298.

3 Present address: The College of Human Medicine, Michigan State University, East Lansing, Michigan. 
cal changes which occur after the removal of the pituitary from the hypothalamus as a progressive sequence of events rather than as a single observation taken at only one stage after isolation.

\section{MATERIALS AND METHODS}

\section{Animals}

Anterior pituitaries from adult, female rats of the Sprague-Dawley strain were used throughout. The animals were housed in air-conditioned quarters; water and food were provided ad libitum and were supplemented once a week with lettuce, oranges, and bread. Vaginal smears were taken by lavage.

\section{Culture techniques}

All rats were sacrificed by decapitation on either the day of proestrus or estrus; the brain was removed from each animal and the pars nervosa and pars intermedia of the pituitary gland were discarded (Kahn, 73). The pars anterior was placed in Earle's balanced salt solution, cut into quarters, and recombined so that four quarters from several glands composed a single culture. The pituitaries were cultivated sterilely by the raft technique (Merchant et al., '64), using Millipore filters (type HA, $0.47 \mu$ ) on stainless steel grids. A chemically defined medium, Trowell's T-8, was used without antibiotics (except where indicated on table 1) and was replaced every three days where applicable. The cultures were gassed continuously with $95 \%$ oxygen and $5 \%$ carbon dioxide. The cultures were divided into seven groups, a group being determined by the length of time in culture ( 4 hours, 3 days,
6 days, 15 days ), by the addition of hypothalamic or cerebral cortical extracts to the media or by the addition of media which had been acidified and reneutralized (control for neural extract cultures). Between six and 26 explants in each group were cytologically examined (tables 1,2 ).

The hypothalamic and cerebral cortical extracts (neural extracts) were prepared in the following manner. The hypothalamus (delimited anteriorly by the posterior edge of the optic chiasma, posteriorly by the posterior border of the mammillary bodies, laterally by the lateral edge of the hypothalamus and $1 \mathrm{~mm}$ in thickness) or an equivalent area of the telencephalic cortex was removed from a female rat in estrus or diestrus and frozen immediately on dry ice. The hypothalamic or cortical areas from several rats were combined and homogenized with a ground glass homogenizer in Trowell's T-8, which had been previously acidified with $1 \mathrm{~N} \mathrm{HCl}$ to approximately $\mathrm{pH} 1.0$. The homogenate was either frozen on dry ice for later use or centrifuged at $25,000 \mathrm{rpm}$ at $4^{\circ} \mathrm{C}$ for one half hour for immediate use. The supernatant was neutralized to approximately pH 7.2 with $2 \mathrm{~N} \mathrm{NaOH}$, sterilized through a Swinney filter containing a Millipore filter $(0.22 \mu)$, and added to the cultures on day three for a three-day period (total of 6 days in culture). The equivalent of two hypothalami or two areas of cerebral cortex was added to each culture. Controls for both types of neural-extract cultures were established by acidifying and reneutralizing the media as described above, omitting, however, the addition of any neural extract. The control and neural extract media were added to the cultures on day three

TABLE 1

Number of pituitaries examined by histological procedures

\begin{tabular}{lcccc}
\hline & $\begin{array}{c}\text { E-OrG-AB } \\
\text { Hollande-Bouin's }\end{array}$ & $\begin{array}{c}\mathrm{KMnO}_{4} \text {-AB-AF } \\
\text { Bouin's }\end{array}$ & $\begin{array}{c}\text { PAS-OrG } \\
\text { formalin }\end{array}$ & $\begin{array}{c}\text { Total } \\
\text { examined }\end{array}$ \\
\hline Uncultivated controls & 5 & 5 & 5 & 15 \\
Four-hour cultures & 8 & 9 & $55^{1}$ & 22 \\
Three-day cultures & 11 & 10 & $55^{1}$ & 26 \\
Six-day cultures & 7 & 8 & $4^{1}$ & 20 \\
Fifteen-day cultures & 10 & 11 & $-6^{1}$ & 6 \\
Neural-control cultures & 3 & 3 & $5^{1}$ & 18 \\
Hypothalamic-extract cultures & 6 & 6 & 6 & 17 \\
Cortical-extract cultures & 6 & 6 & & \\
\hline
\end{tabular}

1 Cultured with 100 units Penicillin $/ \mathrm{ml}$ and $100 \mu \mathrm{g}$ Streptomycin $/ \mathrm{ml}$ of media

E, Erythrosin; OrG, Orange G; AB, Alcian Blue; AF, Aldehyde Fuchsin; PAS, Periodic Acid-Schiff. 
TABLE 2

Number of pituitaries examined by peroxidase technique

\begin{tabular}{lccccc}
\hline & STH & LTH & TSH & FSH & LH \\
\hline $\begin{array}{l}\text { Uncultivated controls } \\
\text { Six-day cultures }\end{array}$ & 3 & 3 & 3 & 4 & 2 \\
$\begin{array}{l}\text { Fifteen-day cultures } \\
\text { Hypothalamic-extract }\end{array}$ & 2 & 3 & 3 & 2 & 2 \\
$\begin{array}{l}\text { cultures } \\
\begin{array}{l}\text { Cortical-extract } \\
\quad \text { cultures }\end{array}\end{array}$ & 2 & 2 & 2 & 2 & 1 \\
\hline
\end{tabular}

for a three day period (total culture time of 6 days).

\section{Histological techniques}

Several histological procedures were used on both cultured and uncultivated glands. Acidophils were identified with an erythrosin-orange G-alcian blue (E-OrG$A B$ ) procedure following fixation for 24 hours in Hollande-Bouin's solution. A 1\% erythrosin (E) solution (erythrosin puriss, blaulich; Chroma-Gesellschaft Schmid and Co.) ( $\mathrm{pH}$ 6.4) was followed by alcian blue (AB) (alcianblau 8GS, Chroma-Gesellshaft Schmid and Co.) in 3\% acetic acid (pH 2.7 ) and finally by $0.5 \%$ orange $\mathrm{G}$ (Or $\mathrm{G}$ ) (Allied Chemical, CI \#16230) in $2 \%$ phosphotungstic acid (pH 2.5).

Two methods were used to identify the mucoid cells. First, sections of pituitary glands, fixed in Bouin's solution for five or 24 hours, were oxidized in acidified $\mathrm{KMnO}_{4}$, stained in the AB-acetic acid solution (as above) and finally stained in aldehyde fuchsin (AF) (Elftman, '59) (basic fuchsin, Allied Chemical, CI \#42500). Secondly, pituitaries were fixed for 72 hours in neutral buffered formol saline and stained with periodic acid-Schiff (PAS) ("traditional method," Lillie, '65) (basic fuchsin, Allied Chemical, CI \#42500) and counterstained in the Or G-phosphotungstic acid solution (as above). Such a procedure differentiates mucoid cells into PASred and PAS-purple subdivisions (Herlant, '64).

In addition to these histological dyes, the peroxidase-labeled antibody technique (P-Ab) (Nakane, personal communication; Nakane and Pierce, '66, '67) was used after Bouin's fixation for the identification of follicle stimulating hormone (FSH), luteinizing hormone (LH), luteo- trophic hormone (prolactin, LTH), somatotrophic hormone (STH) and thyroid stimulating hormone (TSH) cells using appropriate antibodies to each. ${ }^{*}$ These antibodies were absorbed with normal, male rat serum $(1: 1)$ and with rat liver powder (Coons et al., '55) to reduce nonspecific, background staining.

\section{RESULTS}

\section{Erythrosin-Orange G-Alcian blue technique}

Uncultivated control glands. The presumptive STH-secreting cells (OrG + ), the most numerous cells seen, were usually round or ovoid and contained extremely fine brownish-red granules (fig. 1). A second variety of Or $G$ cells had an opaque greenish-yellow cytoplasm with no granulation.

The E + cells (fig. 1), thought to secrete prolactin, were almost as numerous as the Or G cells. Sometimes they were round or ovoid or frequently, they were cupped around large, mucoid cells or had long processes wedged between other cells. The quantity and distribution of the erythrosinophilic granules varied: granules completely filled a few cells but were usually located only around the periphery of the cells or in the long processes. Neither the Or G nor erythrosinophilic cells showed regional distribution within the gland.

Untreated cultures. After four hours of culture, certain cytological changes were apparent in all glands, regardless of fixation and stain. First, the cytoplasmic: nuclear ratio was reduced. Second, fewer cells could be identified as chromophils while the number of chromophobes increased in number. Third, many scattered cells in the four-hour cultures were in some stage of degeneration.

Or G + cells (fig. 2) displayed a homogeneous yellow-orange cytoplasm, no granulation and few negative Golgi images. $\mathrm{E}+$ cells (fig. 2) had decreased in number with granules scattered sparsely throughout the cytoplasm or along the cellular membrane.

4 Rabbit, anti-ovine FSH; rabbit, anti-ovine $I H$ and rabbit anti-porcine I.TH were all generously provided by Dr. Rees Midgley. Rabbit, anti-bovine STH was a gift of Dr. Jacob Furth and rabbit anti-human TSH was supplied by the Endocrinology Study Section, National Institutes of Health. 
Cell processes were less obvious than in the uncultivated gland.

The three-day cultures showed none of the cellular degeneration obvious after four hours in culture. Or G + cells were more numerous than after four hours in vitro, again resembling those seen in the uncultivated gland. Erythrosinophilic granules, however, had continued to decrease in number, and cellular processes were rarely seen.

After six days of culture (fig. 3), no erythrosinophilic granules could be identified while Or G cells showed no appreciable differences from those in the three-day cultures.

Pituitaries cultured for 15 days presented a homogeneous appearance. The cytoplasm of all cells was orange and the cytoplasmic: nuclear ratio was quite small with only a thin rim of cytoplasm around the nucleus. Such a diminution in cell size did not decrease the overall dimensions of the cultures but imparted a fenestrated appearance to the cultures and emphasized the connective tissue septa which intersect the gland. Central necrosis, usually amounting to around $20 \%$ of the total volume, was seen in approximately two-thirds of the explants.

Treated cultures. Pituitaries which had been cultured for three days and which were then cultured for an additional three days with acidified-reneutralized media, hypothalamic extract or cortical extract, did not vary considerably from each other in their histology (figs. 4, 5). In contrast to their absence in the six-day untreated cultures, $\mathbf{E}+$ granules were present in inconsistent numbers in all groups of the treated cultures. No alteration was seen in Or $\mathrm{G}+$ cells from the untreated, six-day explants.

To briefly summarize the results found using the E-Or G-AB technique, the numerous erythrosin granules seen in the uncultivated gland had disappeared by six days in culture. In contrast, the addition of hypothalamic or cortical extracts or the neural control media on day three prevented the complete disappearance of these granules. Orangeophilic cells were the most numerous cells in the uncultivated gland. As time in culture increased, more cells showed an affinity for Or G so that by 15 days in vitro, all cells within the culture were stained with Or G. Hypothalamic and cortical extracts did not seem to alter the morphology of the Or G + cells.

\section{$\mathrm{KMnO}_{4}$-alcian blue-aldehyde fuchsin technique}

Uncultivated control glands. Two mucoid cell types were distinguishable with $A F$ and $A B$ after oxidation with acidified permanganate. The first stained with both $\mathrm{AB}$ and $\mathrm{AF}$ ( $\mathrm{AB}, \mathrm{AF}+$, fig. 6) and appeared a vivid blue-purple in color with a grainy cytoplasm and occasional small purple granules. $\mathrm{AB}, \mathrm{AF}+$ cells were usually large and polygonal, frequently with many processes extending toward the sinusoids and resembled cells usually identified as thyrotrophs. These cells were often seen along the ventral surface of the gland and within the central portion of the lateral wings.

The second cell type was stained a pale purple with AF (fig. 6). These round or ovoid cells resembled gonadotrophic cells and did not display any localization within a section.

Untreated cultures. After four hours in culture both types of mucoid cells still closely resembled those seen in uncultivated control glands. The only difference was the presence of vacuoles either sparsely scattered throughout the cytoplasm or lining the periphery of the cells.

After three days in vitro, mucoid cells were usually located around the periphery of the gland. Although most AB,AF + cells morphologically resembled those in the uncultivated gland, some now showed $A B$ staining only adjacent to the cell membrane. $\mathrm{AB}, \mathrm{AF}$ + cells frequently contained vacuoles and vesicles and were not usually located along sinusoids; rather, they would send along processes toward these vessels.

$\mathrm{AF}+$ cells, the most numerous mucoid cells seen in the three-day cultures, morphologically resembled both the $\mathrm{AF}+$ and $\mathrm{AB}, \mathrm{AF}+$ cells seen in the uncultivated gland and were usually located in clusters along the collapsed sinusoids. Golgi images stained distinctly with $\mathrm{AF}$ and vacuoles and vesicles were also present.

Six-day cultures closely resembled the three-day cultures except that the number 
of cells staining with $A B$ had increased (fig. 7) and the Golgi images of many of the unstained cells (presumably acidophils and chromophobes) were stained with AF.

After 15 days in vitro (fig. 8), the number of mucoid cells had decreased drastically so that, at most, only 15 cells per explant remained. $\mathrm{AB}$ staining was rare; most mucoid cells were stained with AF and contained either large, dense vesicles or numerous vacuoles. The Golgi areas of the majority of all cells in the explant stained with $\mathrm{AF}$ and were quite granular in appearance.

Treated cultures. The addition of the acidified-reneutralized media without any neural extract did not greatly alter the cytology of the mucoid cells from that seen in the six-day, untreated cultures. The addition of either neural extract reduced the number of all mucoid cells from that seen in the six-day untreated cultures.

To summarize the results of the $\mathrm{AB}-\mathrm{AF}$ technique, two mucoid cell types were seen in the uncultivated gland ( $\mathrm{AB}, \mathrm{AF}+$; $\mathrm{AF}+$ ) was affected more radically by culdominant cell throughout the cultivation procedures. After culture AF + cells were usually situated in clusters along the sinusoids, and occasional vacuoles and purple vesicles were seen in the cytoplasm. The number of $\mathrm{AF}+$ cells decreased with increase in culture time, and the addition of either hypothalamic or cortical extracts did not alter this decrease. The second cell type seen in the uncultivated controls $(\mathrm{AB}$, $\mathrm{AF}+$ ) was affected more radically by culture procedures. By three days in vitro, $\mathrm{AB}, \mathrm{AF}+$ cells had decreased in number, displayed only peripheral $A B$ staining and were usually located at a distance from the sinusoids, sending processes toward these vessels. The addition of either neural extract greatly reduced the number of these cells.

\section{Periodic acid-Schiff-orange $G$ technique}

Uncultivated control glands. Two mucoid cells could be distinguished. PAS-red cells (fig. 9) had a reddish-yellow cytoplasm filled with large, irregular red granules; were large and polygonal in size; and displayed prominent Golgi images. Al- though scattered throughout a section, PAS-red cells were often seen in clusters at the ventral and dorsal surfaces and at the center of the lateral wing. PAS-purple cells (fig. 9) showed no localization within a section, were usually round or ovoid in shape and occasionally contained small purple granules.

Untreated cultures. PAS-red cells (fig. 10) were much more common than PAS purple cells after four hours of culture. The cytoplasm of some PAS-red cells stained with Or G but was rimmed at the periphery with a band of bright red granular material.

After three days in vitro, PAS-purple cells were extremely rare. PAS-red cells were also reduced in number, and the granular clumping of the peripheral cytoplasm remained. The number of vacuoles had increased in both cell types.

PAS-purple cells were rare after six days of culture while PAS-red cells continued to display the peripheral granularity. The Golgi images of the unstained cells in the culture were distinctly stained by the Schiff reagent.

After 15 days in culture no PAS-purple cells were seen. PAS-red cells (fig. 11) had decreased in number but still resembled similar cells seen in the six-day explants. Again, Golgi images of unstained cells were PAS + .

Treated cultures. Following the addition of either hypothalamic or cortical extracts, the PAS-red cells with the peripheral granular rim were still more numerous than the rare, PAS-purple cells. The Golgi images of the "acidophils" and "chromophobes" did not show the affinity for PAS that they did in the untreated cultures.

To summarize the results using the PAS-Or G technique, PAS-purple cells decreased considerably in number during culture and the addition of either neural extract did not increase their number. The peripheral granular rim seen in the PASred cells after a few hours of culture diminished slightly after three and six days in vitro but was again predominant after 15 days and with the addition of neural extracts. The PAS-red cells, although decreasing in number during the culture periods, remained more numerous than the 
PAS-purple variety. Both the number of chromophobes and the PAS staining of the Golgi apparatus in acidophils and chromophobes increased with longer culture times; the addition of neural extracts reversed both of the occurrences.

\section{Peroxidase-labeled antibody technique}

Uncultivated control glands. As indicated by peroxidase staining, cells identified with STH antibody (fig. 14) were the most numerous in the anterior pituitary, comprising about a third of the cells. These medium-sized cells, resembling the orangeophils in the E-Or G-AB technique, were round or ovoid and were randomly scattered throughout the gland.

Although the cells demonstrated with anti-LTH (fig. 13) could be distinctly identified, additional cells, presumably STH cells, displayed fainter staining with the LTH antibody. Contrary to previous estimates, the number of LTH cells was second only to the number of STH cells, involving perhaps a quarter to a third of the cells. As with the erythrosinophils, the lactotrophs varied considerably in their morphology being round or polygonal with long processes; many cells were cupped around large spherical cells. There was no specific localization of these cells within any section.

Both the "LH" and "FSH" cells (fig. 12) demonstrated by the peroxidase technique were far less numerous than either of the acidophilic types; occasional cells appeared vacuolated. Both cell types were usually round or ovoid and were scattered uniformly throughout a section.

Although less frequent than other mucoid cells, cells identified with anti-TSH were generally larger than the LH and FSH cells, were polygonal in shape and showed some vacuolation. These cells, predominantly seen in the center of the lateral wing and along the ventral surface of the gland, were infrequent along the lateral and dorsal surfaces and in a band outlining the pars intermedia.

Treated and untreated cultures. The $\mathrm{P}-\mathrm{Ab}$ technique was applied to the six- and 15-day cultures and to the neural-extract cultures. Except for the decrease in cell size common to all the cultured cells, there was no change in the morphology or the number of cells or cell types identified under any of the experimental conditions. That is to say, each cell type identified with an antibody in the untreated and treated cultures retained the same morphology and number seen in the uncultivated controls (figs. 15-19). In contrast with the uncultivated controls, the LTH (fig. 19) antibody did not indicate growth hormone contamination in the cultured explants; indistinct cell outlines were seen in LTH cells under all culture conditions.

\section{DISCUSSION}

A discussion of the cultured pars distalis is relevant only when compared to the cytology of the gland prior to culture. Consequently, the cytology of the normal gland will be considered briefly first, correlating where possible the tinctorial affinities of the cells with their hormonal product.

Cytological studies made during the estrous cycle, pregnancy and lactation demonstrate that prolactin granules in the rat exhibit an affinity for E (Herlant, '60, '64; Pasteels, '63) while growth hormone cells stain with Or G. The morphology of the $\mathrm{E}+$ cells and the cells demonstrated with the LTH antibody in the peroxidase technique are identical: oval to polygonal in shape, many with long processes and many cupped around large basophilic cells (Baker et al., '69; Nakane, '70). Although more numerous than previously reported, the number of $\mathrm{E}+$ cells is far less than the number of cells seen with the LTH antibody, suggesting that not all LTH cells are identified by $\mathrm{E}$ and that previous estimates of prolactin cell numbers based only on histological staining are too low. This discrepancy exemplifies one of the major problems of pituitary cytology using the light microscope. That is, the pituitary cells are identified by the affinity of their granules for a particular dye and if the number or chemical composition of the granules is altered, perhaps by a change in secretion rate of the cells, the cell may lose its affinity for that particular dye; consequently, its ability to be correctly identified is lost. This problem is magnified when analyzing results of cultured glands.

While Herlant ('64) showed that two of the mucoid cells (TSH cells and FSH 
gonadotrophs) were stained with both $A B$ and Gomori's AF after oxidation with acidified $\mathrm{KMnO}_{4}$, we found that with our $\mathrm{AB}, \mathrm{AF}$ technique the TSH cells did stain with both dyes while the FSH gonadotrophs showed an affinity for only the AF. A comparison of these two cell types with cells identified by the $\mathrm{P}-\mathrm{Ab}$ technique shows that the $\mathrm{AB}, \mathrm{AF}+$ cell does correspond to the thyrotroph; the AF + cell contains FSH; and the LH cell does not show an affinity for either stain (Swope et al., '70).

All three mucoid cell types (TSH, FSH, LH) are demonstrated by PAS (Purves, '66) and the addition of the Or G dye further divides these cells into PAS-red and PAS-purple varieties (Herlant, '64). Herlant states that with this technique both gonadotrophs stain red and the thyrotrophs are purple. In our hands, however, the procedure produces the same results as does PAS-methyl blue in the rat (Rennels, '57; Hildebrand et al., '57): the thyrotrophs and one gonadotroph appear red and the second gonadotroph is PAS-purple.

Culturing the anterior pituitary changes its histological picture in several ways. For example, various signs of degeneration are seen in scattered cells of the short-term, four-hour cultures but not in longer term cultures. Similar degeneration was reported by Yamashita ('72) in four-hour explants of mouse anterior pituitaries, and we agree with him that such degeneration is probably due to the mechanical trauma of handling the gland.

The presence of this cellular damage to the explants creates some doubt as to the validity of studies involving short term pituitary cultures or incubations, such as most biochemical or physiological studies on the effect of various hormones, drugs. or hypothalamic releasing factors on the anterior pituitary.

The remaining cultures showed no necrosis except after extended periods in culture when an area of central necrosis was seen in a portion of the explants. This necrosis was not selective as to cell type, involved the entire central portion of the gland and was probably caused by inadequate penetration of nutrients to the core of the explant.

Endocrine activity of the rat anterior pituitary changes radically when the gland is removed from its connections with the hypothalamo-hypophysial portal system. For example, the prolactin cells are released from their hypothalamic inhibition and secrete prolactin in large quantities for seemingly indefinite periods of time (Everett, '54, '56; Meites et al., '61; Nikitovitch-Winer, '65; Kanematsu and Sawyer, '73). However, the production of STH, TSH, LH and FSH from the isolated gland shows a decrease with time so that after pituitary isolation these hormones are released at reduced or basal levels if at all (Nikitovitch-Winer and Everett, '58; Kobayashi et al., '64; Muhlen et al., '73; Steinberger et al., '73).

These hormonal changes produced by isolating the pituitary can be correlated with cytological changes which occur in the cells of the anterior pituitary in culture. The rapidly-secreting prolactin cells discharge their granules into the medium and, therefore, lose their affinity for the erythrosin dye. The granules of the remaining cells are also lost (perhaps due to lysosomal activity (Smith and Farquhar, '66; Farquhar, '71), so that they, too, cannot be identified with the classical dyes. Electron microscopic studies confirm this decrease in secretory granules in all cell types (Rennels, '62; Schelin and Lundin, '71; Yamashita, '72). Consequently, after several days in vitro, pituitary cultures begin to stain homogeneously with the classical dyes. In addition, an enlarged, granular Golgi area is seen in many of the cells; investigators using electron microscopy have identified these cells as prolactin cells (Rennels, '62; Bornstein et al., '72).

Although cell types lose their characteristic staining abilities in culture, the $\mathrm{P}-\mathrm{Ab}$ technique demonstrates beautifully that not only are all the cell types we studied still present after 15 days in vitro, but that they are present in approximately the same ratio as in the uncultivated controls.

Nakane ('71) showed that the P-Ab technique detects some pituitary hormones (STH and LTH) not only in their concentrated state as mature secretory granules, but also at various sites along the secretory pathway (in the cisternae of the endoplasmic reticulum and in the Golgi apparatus) where the hormones are far less concentrated. Thus, the $\mathrm{P}-\mathrm{Ab}$ technique, unlike 
the classical dyes and to some extent even the electron microscope, may not be dependent on the presence or amount of stored, mature hormone within a cell. Baker and $\mathrm{Yu}$ ('71), however, partially refute this hypothesis when they showed that thyroidectomy cells could not always be identified with the P-Ab technique. However, such a discrepancy between their results and ours may lie in the fact that their rapidly-secreting thyroidectomy cells may be releasing a form of TSH which is not recognized by the TSH antibody while the inactive cells (all cell types except prolactin) of the cultured anterior pituitary are storing or retaining a small amount of hormone which may maintain its antigenic potency.

Placing the isolated pituitary in close proximity to hypothalamic tissue again, either by transplantation to the sella turcia of an hypophysectomized animal or by the addition of hypothalamic extract or purified releasing factors to the culture media causes a diminution in the amount of prolactin released and an increase in the secretion rate of the remaining hormones. (Nikitovitch-Winer and Everett, '58; Mittler et al., '69; Mittler et al., '70; Vale et al., '72; Evans, '72; Redding et al., '72; Wakabayashi et al., '72; Crighton, '73). Although it is logical to presume from such data that histological changes should also be obvious within the gland when hypothalamic extract is added, the changes seen here are relatively subtle and minor. For example, the addition of not only the hypothalamic extract, but also the cortical extract and the neural control media stopped the disappearance of $\mathbf{E}+$ granules from the six-day cultures. Such an action by the hypothalamic extract is expected, presumably due to the presence of prolactin inhibiting factor; however, an explanation for the activity of the other two additions is not readily obvious. Furthermore, the number of mucoid cells did not increase in number after the addition of hypothalamic extract, as we anticipated. One possible explanation may explain these results. It is known that cytological changes can occur within the pituitary in a matter of minutes after the injection of releasing factors into the carotid artery (DeVirgilis et al., '68; Couch et al., '69; Coates et al.,
'70; Shiino et al., '72). Since pituitaries in this study were not examined until three days after the addition of extract, the cells may not show the same effects cytologically as would those examined after only a short interval.

The fact that either cortical or hypothalamic extract produces the same histological results cannot be readily explained, nor can the fact that the neural control media altered the usual decrease of granulation in the $\mathrm{E}+$ cells but did not affect the basophilic cells. Perhaps some nonspecific reaction occurred merely from the presence of a different (altered) media.

\section{LITERATURE CITED}

Baker, B. L., A. R. Midgley, B. E. Gersten and Y.-Y. Yu 1969 Differentiation of growth hormone- and prolactin-containing acidophils with peroxidase-labeled antibody. Anat. Rec., 164: 163-172.

Baker, B. L., and Y.-Y. Yu 1971 Hypophyseal changes induced by thyroid deficiency and thyroxine administration as revealed by im. munochemical staining. Endocrinology, 89: 996-1004.

Bornstein, M. B., G. Pelletier and J. Stern 1972 A light and electron microscopic study of rat anterior pituitary in organotypic tissue culture. Brain Res., 40: 489-495.

Coates, P. W., E. A. Ashby, L. Krulich, A. P. S. Dhariwal and S. M. McCann 1970 Morphologic alterations in somatotrophs of the rat adenohypophysis following administration of hypothalamic extracts. Am. J. Anat., 128: 389412.

Coons, A. H., E. H. Leduc and J. M. Connolly 1955 Studies on antibody production. I. A method for the histochemical demonstration of specific antibody and its application to a study of the hyperimmune rabbit. J. Exp. Med., 102: 49-60.

Couch, E. F., A. Arimura, A. V. Schally, M. Saito and S. Sawano 1969 Electron microscope studies of somatotrophs of rat pituitary after injection of purified growth hormone releasing factor (GRF). Endocrinology, 85: 1084-1091.

Crighton, D. B. 1973 The effects of $s ; n$ thetic gonadotrophin releasing factor on the release of luteinizing hormone and follicle-stimulating hormone from ovine pituitary tissue in vitro. J. Endocrinol., 58: 387-391.

DeVirgilis, G., J. Meldolesi and F. Clementi 1968 Ultrastructure of growth hormone-producing cells of rat pituitary after injection of hypothalamic extract. Endocrinology, 83: 12781284.

Elftman, H. 1959 Aldehyde fuchsin for pituitary cytochemistry. J. Histochem. Cytochem., 7: 98-100.

Evans, J. S. 1972 Local intravascular infusion with porcine hypothalamic extract changed the 
cytology and stimulated the secretory activity of rat pituitary autografts. Endocrinology, 90 : 123-130.

Everett, J. W. 1954 Luteotrophic function of autographs of the rat hypophysis. Endocrinology, 54: 685-690.

1956 Functional corpora lutea maintained for months by autografts of rat hypophyses. Endocrinology, 58: 786-796.

Everett, J. W., and M. Nikitovitch-Winer 1963 Physiology of the pituitary gland as affected by transplantation or stalk transection. In: Advances in Neuroendocrinology, A. V. Nalbandov, ed. U. Ill. Press, Urbana, pp. 289-304.

Farquhar, M. G. 1971 Processing of secretory products by cells of the anterior pituitary gland. Mem. Soc: Endocrinol., 19: 79-122.

Herlant, M. 1960 Etude critique de deux techniques nouvelles destinées a mettre en evidence les différentes catégories cellularies présentes dans la grande pituitaire. Bull. Microscop. Appl., 10: 37-44.

1964 The cells of the adenohypophysis and their functional significance. In: International Review of Cytology, G. H. Bourne and J. F. Danielli, eds. Acadernic Press, New York, vol. 17, pp. 299-382.

Hildebrand, J, E., E. G. Renuels and J. C. Finerty 1957 Gonadotrophic cells of the rat hypophysis and their relation to hormone production. Z. Zellforsch., 46: 400-411.

Kahn, R. H. 1973 Rat pituitary explants. In: Tissue Culture, Methods and Applications, P. F Kruse, Jr., and M. K. Patterson, Jr., eds. Academic Press, New York, pp. 114-119.

Kanematsu, S., and C. H. Sawyer 1973 Elevation of plasma prolactin after hypophysial stalk section in the rat. Endocrinology, 93: 238241.

Kobayashi, R., T. Kigawa, M. Mizuno and H. Sato 1964 Study of the gonadotropin secretion of the anterior pituitary cells cultivated in vitro. Gunma Symp. Endocrinol., 1: 249-263.

Lillie, R. D. 1965 Histopathologic Technique and Practical Histochemistry. McGraw-Hill Book Co., New York.

Meites, J., R. H. Kahn and C. S. Nicoll 1961 Prolactin production by xat pituitary in vitro Proc. Soc. Exp. Biol. Med., 108: 440-443.

Merchant, D. J., R. H. Kahn and W. H. Murphy 1964 Handbook of Cell and Organ Culture. 2nd ed. Burgess Publishing Co., Minneapolis.

Mittler, J. C., A. Arimura, and A. V. Schally 1970 Release and synthesis of luteinizing hormone and follicle-stimulating hormone in pituitary cultures in response to hypothalamic preparations. Proc. Soc. Exp. Biol. Med., 133: 1321-1325.

Mittler, J. C., T. W, Redding and A. V. Schally 1969 Stimulation of thyrotropin (TSH) secretion by TSH-releasing factor (TRF) in organ cultures of anterior pituitaries. Proc. Soc. Exp. Biol. Med., 130: 406-409.

Mühlen, A. von zur, U. Junge, R. D, Hesch and J. Köbberling 1973 The release of TSH from organ cultures of human fetal pituitary glands. Acta Endocrinol. (Kbh.) Suppl., 173: 13.

Nakane, P. K. 1970 Classifications of anterior pituitary cell types with immunoenzyme histochemistry. J. Histochem. Cytochem., 18: 1-9. 1971 Application of peroxidase-labeled antibodies to the intracellular localization of hormones. Karolinska Symposia on Research Methods in Reproductive Endocrinology, 3rd Symposium., pp. 190-202.

Nakane, P. K., and G. B. Pierce, Jr. 1966 Enzyme-labeled antibodies: preparation and application for the localization of antigen. J. Histochem. Cytochem., 14: 929-931.

1967 Enzyme-labeled antibodies for the light and electron microscopic localization of tissue antigens. J. Cell Biol., 33: 307-318.

Nikitovitch-Winer, M. B. 1965 Effect of hypophysial stalk transection on luteotropic hormone secretion in the rat. Endocrinology, 77: 658-666.

Nikitovitch-Winer, M. B., and J. W. Everett 1958 Functional restitution of pituitary grafts retransplanted from kidney to median eminence. Endocrinology, 63: 916-930.

1959 Histocytologic changes in grafts of rat pituitary on the kidney and upon retransplantation under the diencephalon. Endocrinology, 65: 357-368.

Pasteels, J. L. 1963 Recherches morphogiques et expérimentales sur la sécrétion de prolactine. Arch. Biol. (Liège), 74: 439-553.

Purves, H. D. 1966 Cytology of the adenohypophysis. In: The Pituitary Gland, G. W. Harris and B. T. Donovan, eds. U. Calif. Press, Berkeley, vol. 1, pp. 147-232.

Redding, T. W., A. V. Schally, A. Arimura and H. Matsuo 1972 Stimulation of release and synthesis of luteinizing hormone (LH) and follicle stimulating hormone (FSH) in tissue cultures of rat pituitaries in response to natural and synthetic LH and FSH releasing hormone. Endocrinology, 90: 764-770.

Rennels, E. G. 1957 Two tinctorial types of gonadotrophic cells in the rat hypophysis. Z. Zellforsch., 45: 464-471.

1962 An electron microscope study of pituitary autograft cells in the rat. Endocrinology, 71: 713-722.

Sanders, A. E., and E. G. Rennels 1959 Evidence on the cellular source of luteotrophin derived from a study of rat pituitary autografts. Z. Zellforsch., 49: 263-274.

Schelin, U., and P. M. Lundin 1971 An electron microscopic study of normal and neoplastic acidophil cells of the rat pituitary. Acta Endocrinol, 67: 29-39.

Shiino, M., A. Arimura, A. V. Schally and E. G. Rennels 1972 Ultrastructural observations of granule extrusion from rat anterior pituitary cells after injection of LH-releasing hormone. Z. Zellforsch. Mik. Anat., 128: 152-161.

Smith, R. E., and M. G. Farquhar 1966 Lysosome function in the regulation of the secretory process in cells of the anterior pituitary gland. J. Cell Biol., 31: 319-347.

Steinberger, A., M. Chowdhury and E. Steinberger 
1973 Effect of repeated replenishment of hypothalamic extract on $\mathrm{LH}$ and FSH secretion in monolayer cultures of rat anterior pituitary cells. Endocrinology, 92: 12-17.

Swope, A. E., R. H. Kahn and J. L. Conklin 1970 A comparison of alcian blue-aldehyde fuchsin and peroxidase-labeled antibody staining techniques in the rat adenohypophysis. J. Histochem. Cytochem., 18: 450-454.

Vale, W., G. Grant, M. Amosa, R. Blackwell and R. Guillemin 1972 Culture of enzymatically dispersed anterior pituitary cells: functional validation of a method. Endocrinology, 91: 562572.

Wakabayashi, K,, J. Antunes-Rodrigues, B.-I. Tamaoki and S. M. McCann 1972 In vitro effect of hypothalamic extract and other stimulating agents on glucose oxidation and luteinizing hormone (LH) release from rat anterior pituitary glands. Endocrinology, 90: 690-699.

Yamashita, K. 1972 Fine structure of the mouse anterior pituitary maintained in a short-term incubation system. Z. Zellforsch., 124: 465478.

Erythrosin-orange G-alcian blue staining after Hollande-Bouin's fixation.

1 Uncultivated control. Several cells are present which display large sparse, erythrosin + granules around their peripheries; these are presumably the prolactin cells (P). Note long process of $\mathbf{P}$ cell in lower left of center. Orange $\mathrm{G}$ cells, the presumptive growth hormone cells $(\mathrm{S})$, and $\mathrm{AB}+$ basophils are also visible (arrow). $\times 1215$.

2 Four hours in vitro. Erythrosin granules are obvious (P). Note long process of prolactin cell in lower right and the prolactin cell capping a basophil in the upper left. Vesicular nuclei (arrow) indicative of degenerative changes are characteristic of this culture period. $\times 1215$.

3 After six days of culture, no erythrosin granules can be seen and the explant begins to stain homogeneously with orange G. $\times 576$.

4 Hypothalamic-extract culture. $\times 1395$.

5 Cortical-extract culture. With the addition of either neural extract, erythrosin granules (P) can still be identified in cells after six days in vitro. $\times 2475$. 

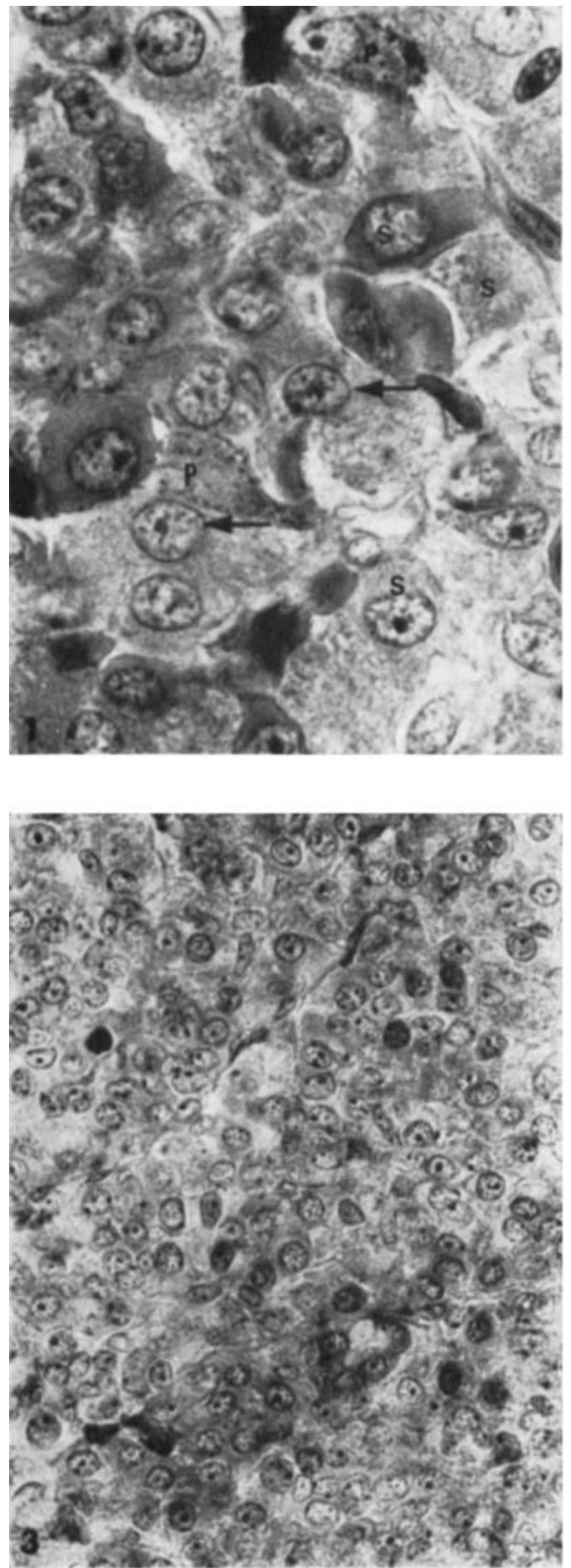
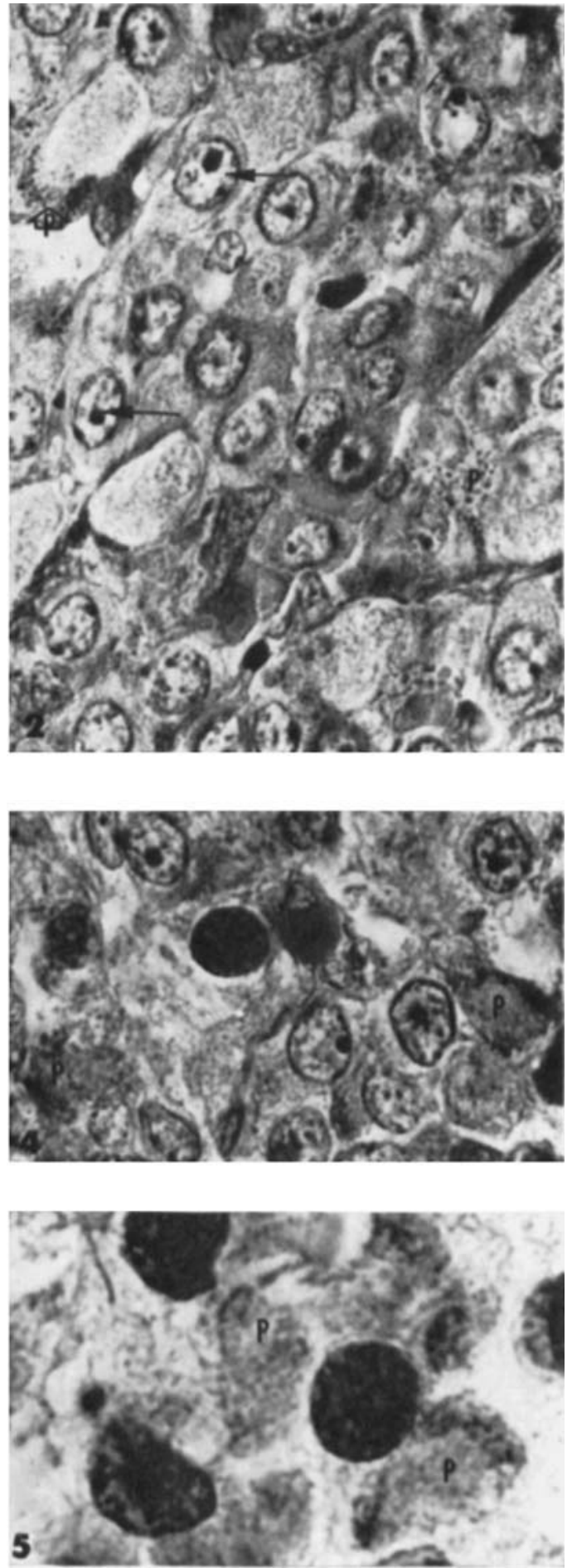
PLATE 2

EXPLANATION OF FIGURES

Figures 6-8: $\mathrm{KMnO}_{4}$-alcian blue (AB)-aldehyde fuchsin (AF) after Bouin's fixation.

6 Uncultivated control showing the large, polygonal AB,AF + cells (the presumed thyrotrophs, T) and the pale AF + cells (a gonadotroph, F). $\times 576$.

7 Six days in vitro. The peripheral localization of the $A B$ stain is evident in the $\mathrm{AB}, \mathrm{AF}+$ cells ( $\mathrm{T}$ ). Several cells containing prominent $\mathrm{AF}+$ granules are also evident (Arrow). $\times 1260$.

8 After 15 days in culture, the mucoid cells are small and sparse (Broad arrow). AF staining of the Golgi apparatus is obvious throughout these cultures (Fine arrow) $\times 495$.

Figure 9: PAS-orange G technique after fixation with neutral, buffered, formol saline.

9 Uncultivated control. PAS-red cells (including the thyrotrophs and one gonadotroph, open arrow) are obvious. PAS-purple cells (the second gonadotroph, closed arrow) are difficult to differentiate from orange $\mathrm{G}+$ cells in a black and white micrograph. $\times 1215$. 

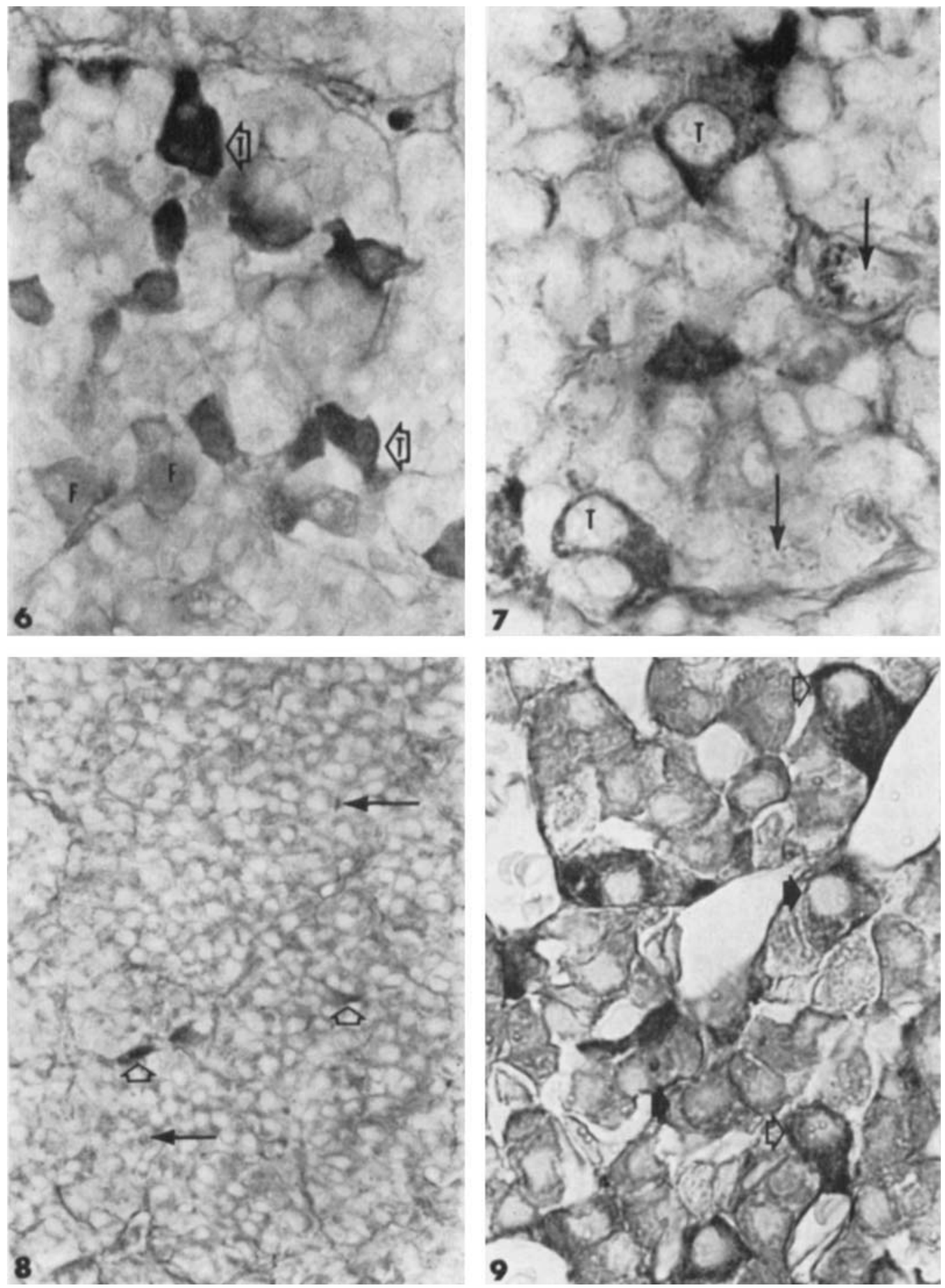
PLATE 3

Figures 10, 11: PAS-orange $G$ technique after fixation with neural, buffered, formol saline.

10 After four hours in vitro, PAS-red cells (Open arrow) are obvious, displaying peripheral, bright red staining properties. PAS-purple cells (Closed arrow) are rare after even this short time in culture. $\times 1260$.

11 Following culture for 15 days, PAS-red cells have decreased in size and number (Open arrow). No PAS-purple cells are seen. PAS staining of the Golgi is obvious (Closed arrow). $\times 1260$.

12 This uncultivated control shows the cells identified with the FSH antibody. The pars intermedia is in the lower left corner of this hemisection of the pituitary. $\times 90$.

13 Cells identified with the LTH antibody in this uncultivated control stain very darkly. Note their long processes and the way they cup around gonadotropic cells (Broad arrow). STH cells also show some staining reaction (Fine arrow). $\times 495$. 


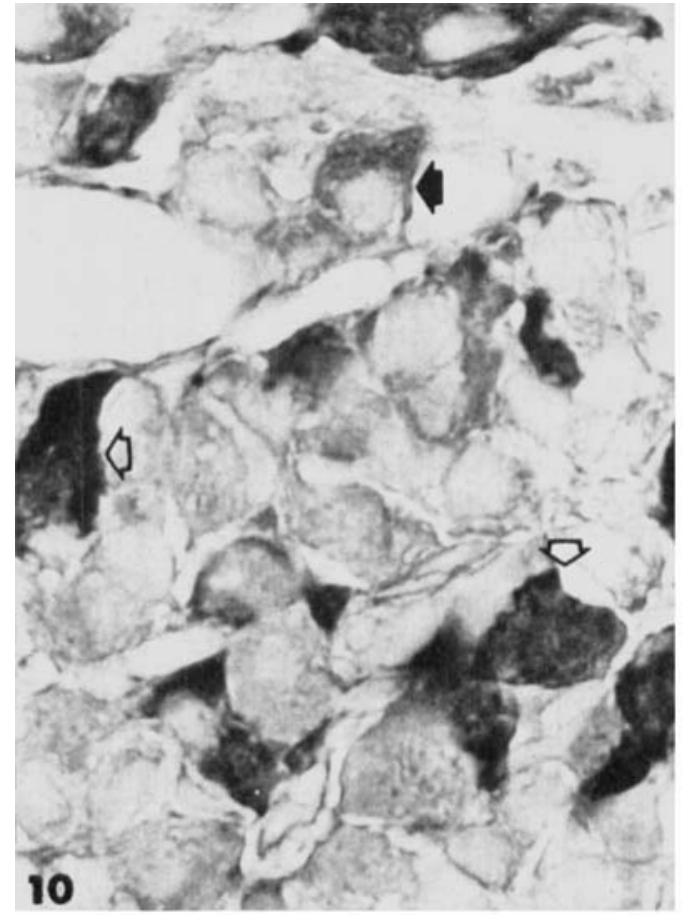

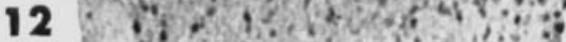

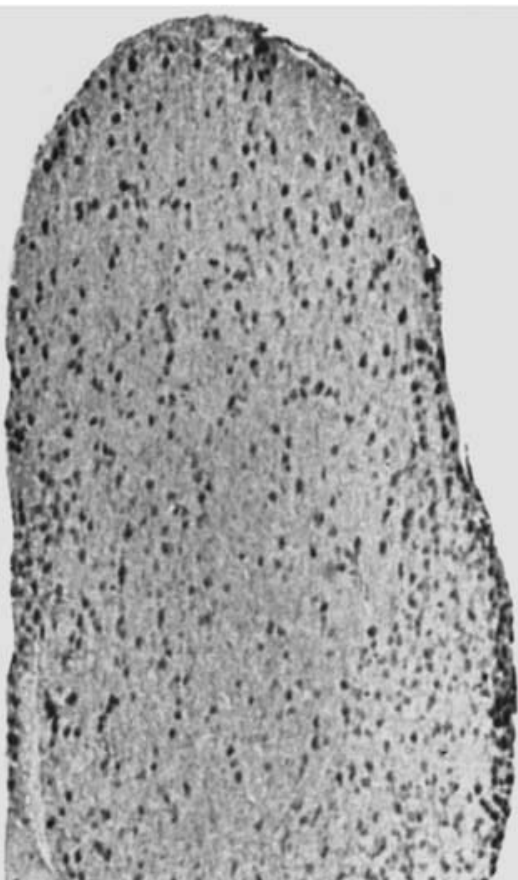

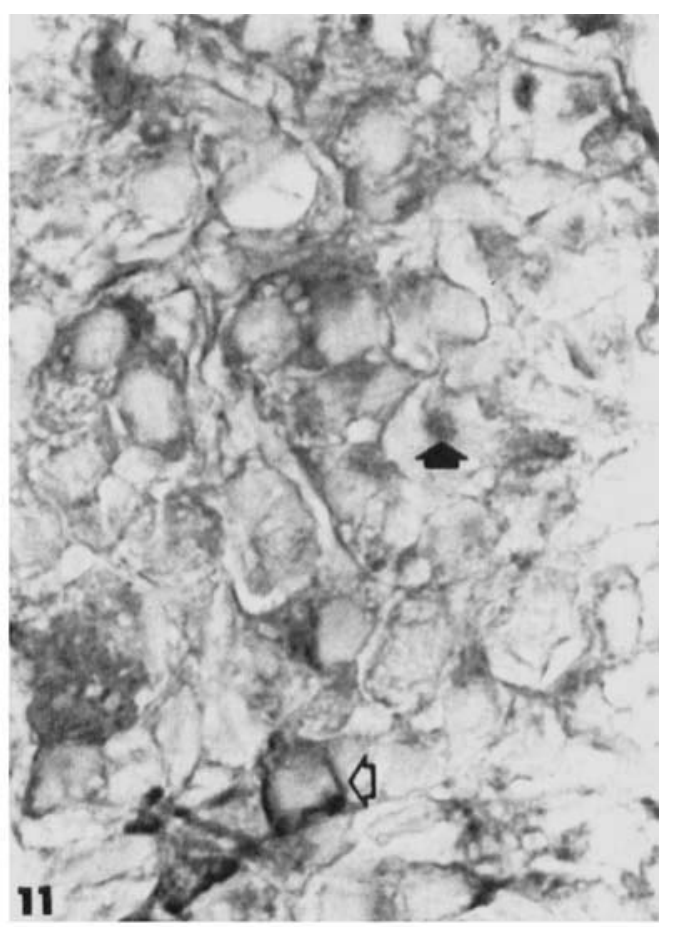

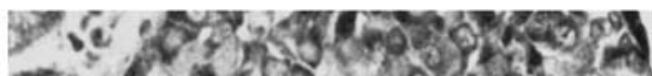

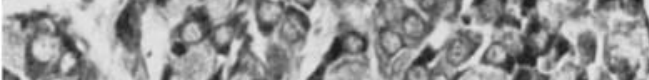

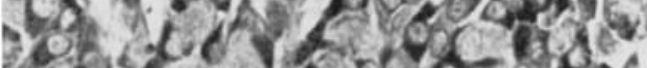

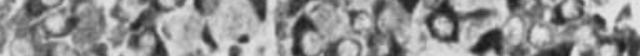

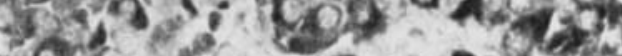
E. ó

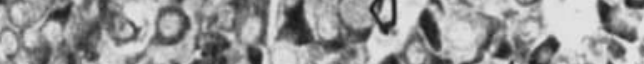

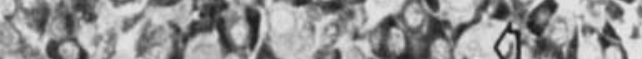

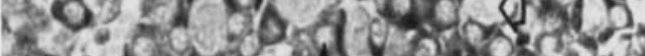

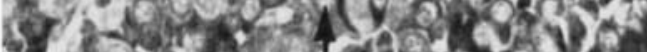

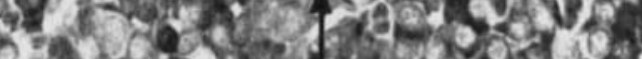

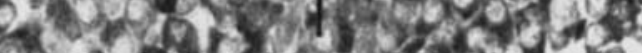

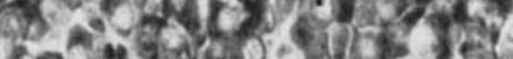
of 30 s

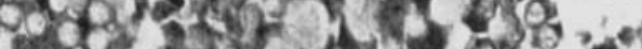

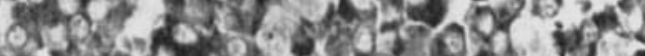

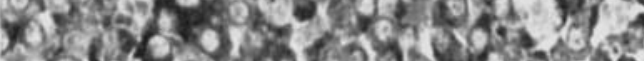

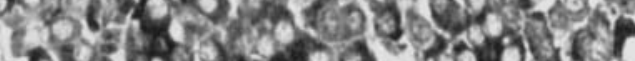

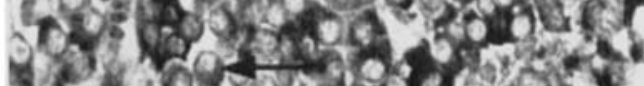

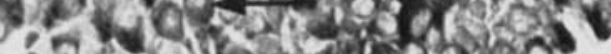
13 . 
PLATE 4

EXPLANATION OF FIGURES

Figures 14-19: Peroxidase-labeled antibody technique following Bouin's fixation.

14 Note the distribution and number of cells identified with the STH antibody in the uncultivated control. The pars intermedia is in the upper left corner of this hemisection of a pituitary. $\times 90$.

15 After six days in culture, cells identified with the FSH antibody are still numerous. $\times 225$.

16 Cells identified with LH antibody show no numerical decrease after 15 days in vitro. $\times 207$.

17 After 15 days in culture, the number of STH cells is also not affected. $\times 207$.

18 The addition of hypothalamic extract did not alter cells identified with the TSH antibody. $\times 207$.

19 Indistinct cell outlines, characteristic of Iuteotrophs under all culture conditions, are evident. Cortical extract has been added to this culture. $\times 207$. 

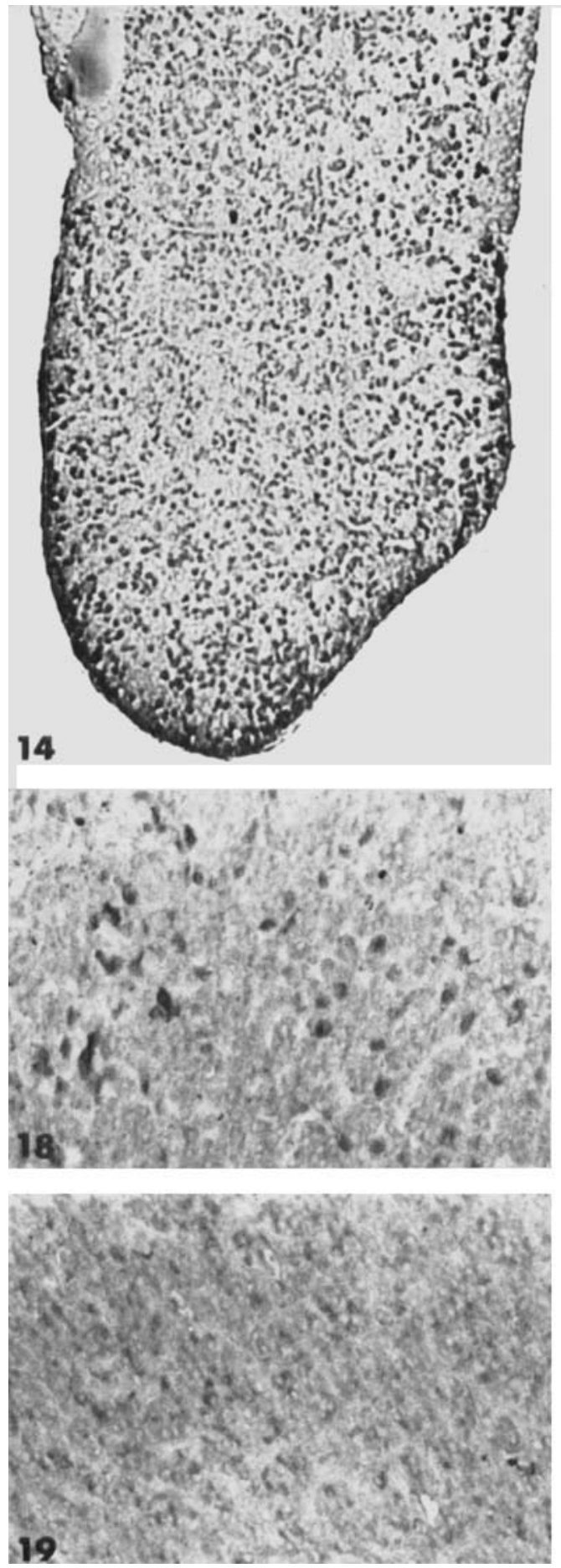
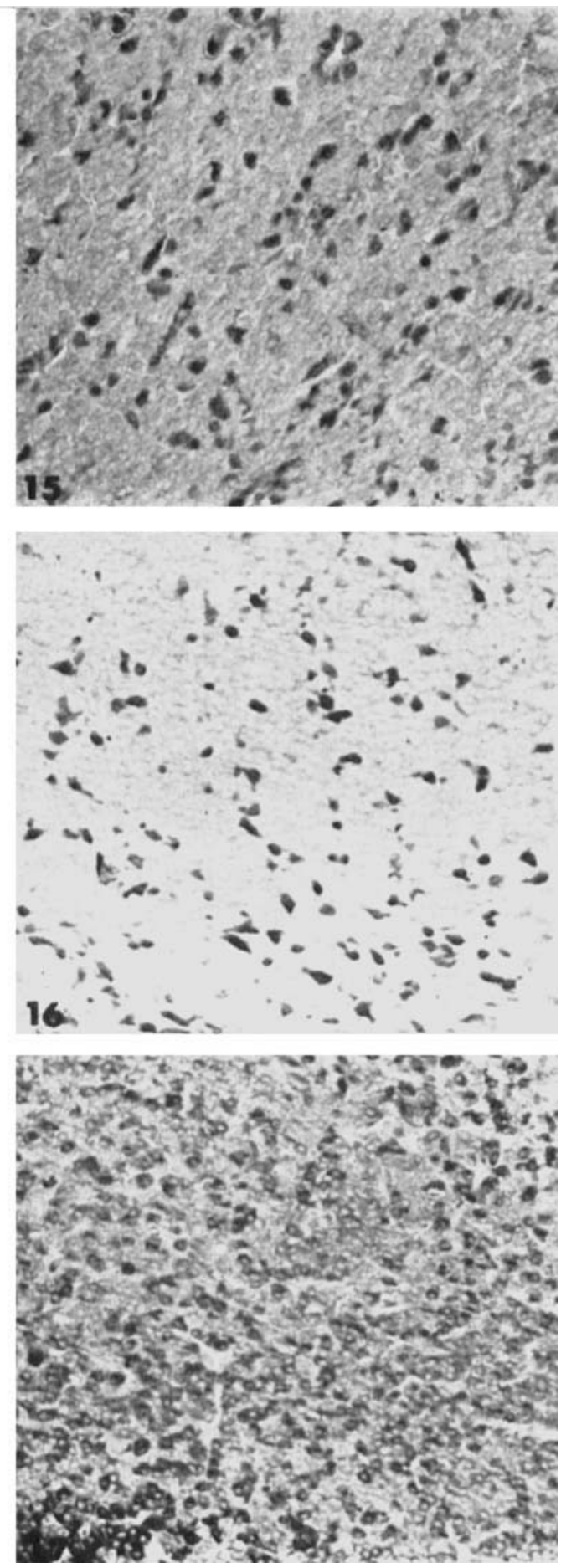